\title{
RECLAMATION OF DISTURBED LANDS IN GLEN CANYON National ReCREATION AREA
}

\author{
CYRUS M. MCKELL $\bullet$ WeBER STATE UNIVERSITY \\ OGDEN
}

\section{$\checkmark \quad$ INTRODUCTION}

At Glen Canyon National Recreation Area (GCNRA) a number of disturbed sites require revegetation for aesthetic reasons and to maintain their natural appearance as part of the setting expected of a National Park or Recreation Area. Old road ways, decommissioned service areas, construction sites and bare areas characterize such sites. The purpose of this project is (1) to conduct a literature review of revegetation reports pertinent to the climate and conditions of GCNRA and, (2) to establish two revegetation study areas at sites selected in consultation with NPS. Revegetation is necessary for functional reasons: 1) to prevent soil erosion and maintain or support the ecological balance of functioning ecosystems adjacent to the disturbed areas, and 2) to restore natural functions such as nutrient cycling, hydrology, soil stability and plant growth of the sites. Two of these sites were chosen as the location for revegetation tests.

Revegetation of disturbed sites in arid regions is difficult and often risky under the inherently harsh and highly variable conditions of such locations (Van Epps and McKell 1980). Nevertheless, revegetation is possible, as evidenced by the natural return of plants to disturbed sites over long periods of time when the site has been conditioned by natural process such as a build up of litter, soil surface stabilization, natural increase in seeds and a favorable sequence of weather conditions. The research task is, therefore, to learn what soil, litter, or surface conditions and factors can be created or manipulated to successfully achieve revegetation where and when it is needed.
Disturbed sites in the GCNRA present some of the most difficult challenges for revegetation because of the arid climate of the region. For example, annual precipitation at Lee's Ferry, Arizona is $155 \mathrm{~mm}$ and at Hanksville, Utah $144 \mathrm{~mm}$. A major portion comes in late-summer when precipitation effectiveness for seedling establishment is minimal, mostly because of high temperatures and evaporation rates.

Another adverse factor for plant establishment is the soils of the NRA. Generally, the soils are predominantly sandy with very little organic matter and only a minimum of clay and silt. Thus, water holding capacity is low, water permeability is high and nutritional supply is low which all combine to increase the risk for plant establishment (Packer and Aldon 1978). Some disturbed sites such as old roads or construction areas present additional challenges of being compacted and/or having a topdressing of gravel. Recreation is the major land use of the GCNRA but other uses such as cattle grazing are permitted. However, the primary focus is on aesthetics as a background for water-based recreational use.

The challenge and purpose of the project is to provide an information base on the feasibility and conditions necessary for revegetation of disturbed sites in the arid climates and sandy soils of GCNRA. The purpose of this report is to report plot plans and preliminary revegetation results at GCNRA.

\section{ESTABLISHMENT OF STUDY PLOTS AT GLENN CANYON NRA}

Two sets of plots were established, one at 
Page, Arizona and the other at Hall's Crossing, Utah. Close coordination with professional staff of GCNRA assured that the plot areas were placed in sites typical of problem areas that require revegetation. Thus, the plots could fulfill their purpose: to provide guidance and a reference for future revegetation plans at GCNRA. The methods, species and treatments used in designing the study plots were adapted from studies and results in the general area of the Southern Colorado Plateau and the 4-corners area of the U.S. (Fuller 1987).

The Hall's Crossing test site is in a garbage, refuse disposal area where a top dressing of sandy soil was spread over the disposed materials. As a result, the soil is not densely packed and contains seeds of aggressive annual plants. The Page test site is in an area where heavy equipment and vehicles were located during construction of the dam in the 1940 's. Not only was the soil compacted but a layer of gravel was also applied and thus natural revegetation of these sites has not occurred. The vegetation of the areas surrounding each of the disturbed sites is in the upper Sonoran Desert (Küchler 1964) and is delineated in the warm desert shrub vegetation type (Küchler 1964). Some of the dominant plant species of the general area include blackbrush (Coleogyne ramosissima), green ephedra (Ephedra viridis), sand sagebrush (Artemisia filifolia), indian rice-grass (Oryzopsis hymenoides), curly mesquite grass (Hilaria jamesii), sand dropseed (Sporobolus cryptandrus), and desert mallow (Sphaeralcea spp.). In higher elevations or mesic sites, juniper (Juniperus osteosperma), desert holly (Berberis fremontii), and saltbrush (Atriplex spp.) may be found along with various perennial and annual herbs.

No hypotheses were directly tested in setting up the project. However, the choice of species and establishment methods make it possible to subsequently test the following hypotheses:

1. In stress environments, plant establishment is more successful with transplants than from seeds.

2. Plant establishment is more successful with native shrubs than with native grasses.

3. Some native species are easier to establish in stress environments than others given an array of choices.

4. Additional treatments such as surface mulch and small basins around transplants increases plant establishment and survival more than no mulch and level planting. (Several comparisons of treatment combinations are possible with the plot design of treatments.)

\section{$\checkmark \quad$ STUDY AREAS}

\section{PAGE, ARIZONA}

The plots at Page, Arizona were located East of Highway 89 about $1.6 \mathrm{~km}$ North of the dam in the area of the viewsight. The area of the test site was a former construction and heavy equipment location used during construction of the dam. It had been top dressed with about $7.5 \mathrm{~cm}$ of gravel and compacted. Very little vegetation was growing on the area possibly due to the gravel and compacted surface. Prior to plot establishment the area was ripped by a bulldozer to a depth of $15-25 \mathrm{~cm}$ which mixed the underlying sandy soil with the gravel surface and loosened the compaction. The ripping action left the surface of the area with furrows and ridges (20-25 cm deep) which were intended to serve as a protection from wind blowing and to harvest some of the meager precipitation to seeds and transplants in the bottom of the furrows. Just prior to the day of plot establishment on April 8, 1990, a rain occurred which left the soil moist to a depth of $7.5 \mathrm{~cm}$.

\section{HALL'S CROSSING, UTAH}

The field plots at Hall's Crossing were established on April 10, 1990. They were located on an area that had been used for a number of years as a disposal area that had been covered with sandy soil in a previous year and compacted only to the extent of density as would be obtained with the equipment used to cover the disposed material. The alternative site was an abandoned roadway which was available for test plots but was extremely dry and compacted at the time of plot establishment. The dump site was selected because it provided an opportunity to test planting methods on a fill site as contracted with the compacted area already chosen for the Page, Arizona plots. Very little vegetation was growing on the disposal site except for a few small russian thistle and an annual grass (species unknown because of the 
immaturity of the plants). Native vegetation existed on the North and East side of the study area.

\section{$\checkmark \quad$ METHODS FOR PLOT} ESTABLISHMENT

\section{BACKGROUND AND INFORMATION FOR PLANTS USED IN PLOTS AT PAGE AND HALL'S CROSSING}

Seeds and plant materials were obtained from two sources. Granite Seed Company of Lehi, Utah provided all of the seeds used to plant the plots in treatment 1 in both field locations. These same seed lots were used to propagate seedlings of most species in the Botany Department greenhouse of Weber State University. Three species were not propagated from the Granite Seed Company seed lots. Blackbrush was propagated from cuttings taken from plant sources near the field plots and rooted in the greenhouse. The key steps in vegetative propagation of this species were; collection of cuttings during the dormant condition, use of a rooting hormone, and use of a propagation mist and bottom heat on the rooting bench. Juniper and Roundleaf buffaloberry were obtained from the Porter-Walton nursery in Centerville, Utah as 1-gallon can transplants four months prior to field planting. They were conditioned to outplanting during the waiting period by being held outside in a protected area. At the time of planting they were in excellent condition. All of the plants grown in the greenhouse were conditioned to outside environment by maintaining cool conditions and reduced irrigation prior to outplanting.

\section{ESTABLISHING THE PAGE, ARIZONA FIELD PLOTS}

At Page, Arizona, each plot was 2 furrows wide and 2 meters long making a total area of approximately 39.6 meters wide and 31.9 meters long. The experimental design consisted of:

4 treatments -
A. Seeded (plots 1-10)
B. Planted (plots 11-20)
C. Plated in small basins (plots 21-30)
D. Planted in basins and mulched plots 31-40)

10 species -
1. Juniper (Juniperus osteosperma)

2. Roundleaf buffaloberry (Shepherdia rotundifolia)

3. Fourwing saltbush (Atriplex canescens)

4. Green ephedra (Ephedra viridis)

5. Blackbrush (Coleogyne ramosissima)

6. Indian ricegrass (Oryzopsis hymenoides)

7. Galleta (Hillaria jamesii)

8. Sand dropseed (Sporobolus cryptandrus)

9. Desert marigold (Baileya multiradiata)

10. Scarlet gilia (Gilia aggregata)

8 replications

Thus with 4 treatments, 10 species and 8 replications there were 320 individual plots. Because of the large number of plots the arrangement of species and treatments was systematized to avoid errors in planting. The species were kept in sequence but the treatments were rotated within the replication. All transplants received 1 liter of water and a fertilizer tablet in the bottom of the planting hole. Greenhouse grade peat moss was used as a mulch in treatment 4 involving transplanting in a basin. Peat was also used in the seeding, treatment 1 , by placing about 25 seeds in a $20 \mathrm{~cm}$ diameter circle on peat moss and covering them with $.6 \mathrm{~cm}$ of soil to simulate natural conditions of seeds falling from a plant and being covered with litter and wind-blown soil.

\section{ESTABLISHING THE HALL'S CROSSING PLOTS}

At the Hall's Crossing site the plots were 1.5 $x \mathbf{1 . 5}$ meters square and comprised a total area of 20 meters by 22.5 meters. A larger plot area was not possible because of local influences that would have reduced plot uniformity. The experimental design was almost identical to the one used at Page, Arizona with the exception that Desert mallow was used instead of Desert marigold and Scarlet gilia because of insufficient plant materials for these two species. The experimental design consisted of the following:

4 treatments -
A. Sceded (plots 1-9)
B. Planted (plots 10-18)
C. Plated in small basins (19-27)
D. Planted in basins and mulched (28-36)

9 species -

1. Juniper (Juniperus osteosperma)

2. Blackbrush (Coleogyne ramosissima)

3. Roundleaf buffaloberry (Shepherdia rotundifolia)

4. Fourwing saltbush (Atriplex canescens)

5. Green ephedra (Ephedra viridis)

6. Indian ricegrass (Oryzopsis hymenoides)

7. Galleta (Hillaria jamesii) 
8. Sand dropseed (Sphaeralcea ambigua)

9. Desert Mallow (Sphaeralcea ambigua)

8 replications.

Thus, with four treatments, 9 species and 8 replications there were 288 individual plots. As with the Page study plots the species were numbered consecutively and not randomized to avoid errors in planting. The four treatments were rotated among locations within the replications to provide a different exposure to site variability. All transplants received 1 liter of water and a fertilizer tablet in the bottom of the planting hole at the time of planting. Greenhouse grade peat moss was used for mulch on the seeding (treatment 1) and the basin planting (treatment 4). About 25 seeds were placed on the peat moss and covered with $.5 \mathrm{~cm}$ of soil to simulate natural conditions. At the time these study plots were established the soil was almost dry possibly because of the uncompacted condition and sandy nature of the soil even though a small amount of precipitation had been received about 3 days earlier.

On March 14, 1991 at Page and March 17 at Hall's Crossing, almost one year after the plots at both locations were established, a preliminary survey was made of the condition of the transplanted species. Because of the preliminary status of the survey and because plants were still to be planted, no statistical analysis was warranted. The year following planting and seeding had been below average in precipitation for the region and poor transplant survival and seedling germination was expected, based on results of other revegetation work in arid regions. At Page, 20 plots in treatment 1 contained seedlings with Atriplex and Hilaria dominating. Because many of the species in the study have a hard seed character, the lack of seedlings one year later is not an indication of failure but must be monitored for several years to determine if germination and seedling growth will occur under some future combination of favorable conditions. In treatment 2, twenty-nine transplants survived with Atriplex and Sporobolus being the largest in number. In treatment 3, twenty transplants survived with Atriplex in the majority. In treatment 4, Atriplex was again the leading survivor.

The numbers of plants on the Page plots are indeed encouraging for such an arid region and during a relatively dry year. The creation of ridges and furrows is possibly one of the favorable aspects of this field trial. At the time the plots were visited, very young seedlings of Russian thistle were emerging and could be expected to create problems for seedlings and transplants later in the growing season. Areas left bare for so long such as this old construction site may have a large volume of seeds in the surface soil which can pose problems for subsequent plant establishment.

Results at the Hall's Crossing plots were very poor. On the seeded treatment only four plots had any seedlings on them with Hilaria being the greatest. Treatment 2 had no surviving transplants and treatment 3 had only two, Buffaloberry and Atriplex. Treatment 4, which was designed to provide the most favorable conditions for plant survival did not have any transplants that appeared to be alive.

\section{- CONCLUSIONS}

A hasty conclusion should not be reached at this time regarding plant establishment by the various species and the treatments most suitable for their survival. Many plants are able to die back to the crown in the early seedling stage and regenerate when conditions become more favorable. Seeds will germinate when favorable conditions occur. Hard seeded species require more time to gradually soften their seed coat and germinate when favorable conditions occur for the seeds remaining in the topsoil in an accumulation of litter. Further observation of these plots will be required before any final conclusion can be reached.

\section{$\checkmark \quad$ LITERATURE CITED}

Fuller, William W. 1987. The selection of species for revegetation. pp. 109-131 In Charles Reith and Loren Potter (eds.). Principles and Methods of Reclamation Science. University of New Mexico Press. Albuquerque, NM.

Küchler, A. W. 1964. Potential natural vegetation of the coterminous United States. Am. Geog. Soc. Special Publication 36. 154 pp.

Packer, P. E. and E. F. Aldon. 1978. Revegetation 
Reclamation of Drastically Disturbed Lands. F. W. Shaller and P. Satton (eds.), Range ASA.

Van Epps, Gordon A. and Cyrus M. McKell. 1980. Revegetation of disturbed sites in the salt desert range of the Intermountain range of the U.S. Utah Agr. Exp. Sta. Land Rehabilitation Series No. 5. $53 \mathrm{pp}$. 